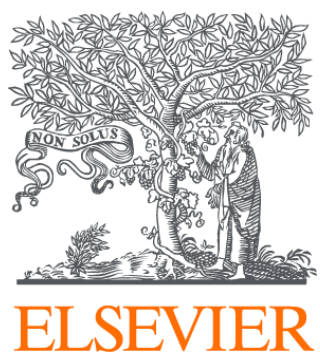

Since January 2020 Elsevier has created a COVID-19 resource centre with free information in English and Mandarin on the novel coronavirus COVID-

19. The COVID-19 resource centre is hosted on Elsevier Connect, the company's public news and information website.

Elsevier hereby grants permission to make all its COVID-19-related research that is available on the COVID-19 resource centre - including this research content - immediately available in PubMed Central and other publicly funded repositories, such as the WHO COVID database with rights for unrestricted research re-use and analyses in any form or by any means with acknowledgement of the original source. These permissions are granted for free by Elsevier for as long as the COVID-19 resource centre remains active. 


\title{
Government lending in a crisis
}

\author{
James R. Brown ${ }^{\text {a, }}$, Gustav Martinsson ${ }^{b}$, Christian Thomann ${ }^{c}$ \\ ${ }^{a}$ Iowa State University, Ivy College of Business, Department of Finance, 2333 Gerdin Business Building, Ames, IA 50011-2027, United States of \\ America \\ ${ }^{\mathrm{b}}$ KTH Royal Institute of Technology, Swedish House of Finance (SHoF), Lindstedtsvagen 30, SE-10044 Stockholm, Sweden \\ ${ }^{\mathrm{c}}$ Stockholm School of Economics, Department of FInance, KTH Royal Insitute of Technology, Drottninggatan 98, SE-11160 Stockholm, Sweden
}

\section{A R T I C L E I N F O}

\section{JEL codes:}

H12

H81

G01

G18

G32

G33

Keywords:

Liquidity management

Financial crisis

Government policy

Leverage

Financial distress

COVID-19 policy

\begin{abstract}
A B S T R A C T
The economic disruption from the COVID-19 pandemic prompted governments around the world to initiate an unprecedented number of temporary lending and tax deferment programs. Which firms will benefit from these programs? What are the implications for firm balance sheets and post-crisis survival? We provide some novel insights on these questions by studying one of the first government programs of this type, which Sweden launched at the height of the 2008-2009 financial crisis. The Swedish program allowed firms to temporarily suspend payment of all laborrelated taxes and fees, treating these deferred amounts as a short-term loan from the government. Firms participating in the program are younger, less profitable, hold fewer cash reserves, are more leveraged, and have less unused slack in their credit lines when the crisis hits. Given the structure of the Swedish program, it provided more liquidity to firms with relatively larger ex ante wage bills. Exploiting this feature of the policy, we find that firms use the program to increase overall debt levels rather than to substitute for other borrowing. The leverage increase is due entirely to higher levels of non-bank debt. Firms use the funds to avoid making even deeper cuts to current assets. Despite the increase in leverage, access to the lending program is unrelated to the likelihood a firm files for bankruptcy and is negatively related to the likelihood a firm encounters severe financial distress in the years immediately following the crisis.
\end{abstract}

\section{Introduction}

Can policy help mitigate the consequences of negative liquidity shocks? In the wake of the financial crisis, an important literature emerged on the macro implications of monetary policy and other broad government interventions aimed at alleviating (or avoiding) severe financial market disruptions. ${ }^{1}$ There has been much less attention, however, to the effects of micro-level policies targeting firms facing steep but transitory liquidity shortfalls.

In this paper we study one such policy, which Sweden launched at the height of the financial crisis. The Swedish program allowed

We are grateful to Laurent Bach, Geraldo Cerqueiro, Douglas Cumming (the editor), Karolina Ekholm, Rickard Eriksson, Daniel Foos, Joan Farre-Mensa, Christopher Goetz, Bronwyn Hall, Johan Hombert, Ulf von Lillienfeld-Toal, Hans Lindblad, Pierre Mohnen, Barbro Olsson, Maria Fabiana Penas, Bruce Petersen, Mark Schankerman, Per Strömberg, Joacim Tåg, and two anonymous referees for helpful feedback on this research project.

* Corresponding author.

E-mail addresses: jrbrown@iastate.edu (J.R. Brown), gustav.martinsson@indek.kth.se (G. Martinsson), christian.thomann@hhs.se (C. Thomann).

${ }^{1}$ For example, see Taylor (2009), Claessens et al. (2010), French et al. (2010), and Schularick and Taylor (2012). 
firms to postpone paying all of the labor-related taxes and fees typically due to the government at the end of each month. These payments are relatively high in Sweden and include withheld personal income taxes, as well as fees to cover employees' social security, government provided health insurance, and workers compensation. For firms choosing to take advantage of this temporary tax deferment, all suspended payments were treated as a loan from the Swedish government, and all such loans were charged a fixed and non-trivial interest rate (approximately 5.3\% per year) to discourage firms that were not liquidity constrained from delaying their regularly scheduled tax payments. The Swedish program differed sharply from traditional government lending programs, which generally take the form of longer-term grants to small businesses, loan guarantees to particular types of firms, and/or the opportunity to reduce taxes by accelerating deductions and depreciation on certain types of investment. ${ }^{2}$

We start by studying how pre-crisis firm characteristics influence the decision to participate in the government lending program. The firms sorting into the program generate less internal cash flow, are younger, have fewer cash reserves, and make lower dividend payouts. Notably, two of the most important positive predictors of program participation are the firm's pre-crisis leverage ratio and the fraction of its granted credit credit lines already used. Overall, the government program provides liquidity to firms who have already used up their available debt capacity and have insufficient resources to internally buffer the shock.

To evaluate the policy's effects on firm balance sheets, we exploit a feature of the policy that caused sharp differences across firms in the amount of liquidity they could obtain from the tax deferment. Although the option to postpone these payments was available to almost all Swedish firms, the amount of liquidity they would gain from doing so differed sharply across firms based on the relative magnitude of their monthly labor tax payments. In this way, some firms were positioned based on ex ante firm characteristics to gain more liquidity from the policy. To measure a firm's exposure to the program, we construct a proxy for the maximum amount of liquidity the firm could obtain (relative to the firm's size) using information on firm-level wage bills in the pre-program period (2006-2008). We refer to this value as the firm's Loan capacity. Not surprisingly, this measure strongly predicts program participation, after controlling for the other characteristics noted above.

Our tests focus on whether participating firms with a higher Loan capacity are disproportionately responsive to the lending program compared to participating firms with a relatively low Loan capacity. The key assumption underlying this approach is that, although the decision to delay tax payments is clearly endogenous, the extent of treatment from the policy (within the sub-set of firms sorting into the program) is exogenous to firm borrowing decisions. Supporting this assumption, we find no evidence that a firm's Loan capacity is related to debt growth in the pre-event time period.

In sharp contrast, in the year the program is put in place there is a substantial differential increase in total debt among participating firms with a higher Loan capacity. Specifically, total debt growth is approximately $20 \%$ higher for participating firms in the top quartile of Loan capacity compared to participating firms in the bottom quartile. Moreover, the debt growth is confined entirely to non-bank debt, as it should be if the debt growth is due to the government program. Swedish firms used the government program to increase net debt levels, rather than to substitute for other for other borrowing (e.g., Banerjee and Duflo (2014)).

The funds firms raised through the government program also affected the asset side of the balance sheet. Using the same approach, we find that participating firms with a higher Loan capacity have disproportionately faster growth in current assets. On average, firms are drawing down liquid assets during this period, so access to the government program appears to allow firms to avoid making even deeper cuts to their short-term assets. We find no relation between exposure to the lending program and growth in fixed assets.

We conclude with evidence on survival and financial distress in the years immediately following the introduction of the lending program. Despite the increase in debt among already highly leveraged firms, firms more heavily treated by the lending program are not any more likely than other participating firms to file for bankruptcy in the immediate post-crisis period. In fact, more exposure to the program is associated with a substantial reduction in the likelihood a firm encounters severe financial distress during this period.

Overall, our findings are consistent with the idea that government lending programs in a crisis can alleviate short-term liquidity constraints in otherwise healthy firms. Firms do not use the government funds to substitute for other borrowing, nor do they exit at unusually high rates after obtaining the funds. Moreover, the effects are strongest for firms with high Loan capacity and a greater propensity to face binding financing constraints in a crisis.

Our findings add to a set of studies on the effects of government policy efforts to alleviate credit constraints in certain types of (typically small) firms. For example, Banerjee and Duflo (2014) show that firms eligible for a targeted lending program in India used the funds to expand production rather than substitute for other borrowing, and Bach (2014) finds that plausibly exogenous extensions to a targeted credit program in France led to substantial increases in the use of (subsidized) debt financing (also see Lelarge et al. (2010)). Similarly, Brown and Earle (2017), studying a comprehensive sample of Small Business Administration (SBA) lending in the U.S., link funding from SBA loans with firm-level employment growth. Our paper also shows how government programs can address credit constraints, but we study one of the first policies we know of focusing specifically on liquidity provision in a crisis, when credit constraints are likely unusually severe, even among firms not typically constrained.

Our study relates to the large literature on the effects of changes in funding conditions, particularly the strand of this literature focusing on liquidity management when firms face negative finance shocks. ${ }^{3}$ Much of this research focuses on evaluating the impact of

\footnotetext{
${ }^{2}$ Many of these programs focus on small- and medium-sized firms, such as the"Comptes pour le developpement industriel" targeted credit program in France (e.g., Bach (2014)) and the loan guarantees provided by the U.S. Small Business Administration (e.g., Brown and Earle (2017)). Beck et al. (2010) discuss loan guarantee programs around the world. For evidence on the effects of tax deferral policies more broadly, see Armstrong et al. (2012), Edwards et al. (2016), Zwick and Mahon (2017), Ohrn (2019), and Shevlin et al. (2019).

${ }^{3}$ For example, see Duchin et al. (2010), Campello et al. (2010), Denis (2011), Casey and O’Toole (2014), Berger et al. (2015), Bliss et al. (2015), Brown and Petersen (2015), Fernández et al. (2018)), Brown et al. (2021), and Almeida (2021).
} 
credit constraints and identifying the internal adjustments firms make in response to these constraints. Our findings suggest that access to liquidity (via temporary lending or tax deferment programs) during a crisis can have important effects on firm activities.

Finally, although the Swedish program was novel when it was introduced in 2009, governments around the world introduced similar programs in response to the COVID-19 pandemic. As we summarize in Table 7, approximately 75\% of OECD countries initiated some type of temporary lending and/or tax deferment program in 2020 . These programs offered liquidity that was easy to access, tied in some way to labor taxes or payroll expenses, and only accessible for a short window during the crisis. In this way, our work provides a timely evaluation of one policy tool governments are increasingly interested in using to address transitory but sharp economic disruptions.

\section{The Swedish lending program}

\subsection{Institutional setting}

The severity of the 2008-2009 financial crisis prompted the Swedish government to implement a number of measures aimed at ensuring financial stability. ${ }^{4}$ Despite these initiatives, the Swedish government was concerned that the financial crisis had spilled over to the real economy, constraining liquidity in otherwise healthy firms. ${ }^{5}$ It is evident from Fig. 1 that firms perceived financing conditions in Sweden to be unusually difficult in late 2008 and early 2009. In November of 2008 the Swedish National Institute of Economic Research began surveying firms about their ability to access finance. In April of 2009, around the height of the financial crisis, more than $15 \%$ of Swedish firms stated that it was "considerably harder than normal" to access finance. The fraction of firms stating it was considerably harder than normal to access finance declines throughout 2009 and 2010, but this fraction does not fall below $10 \%$ until the end of 2009 , and is above $5 \%$ until 2010. After the crisis abates, the fraction of firms stating that it is harder than normal to access finance fluctuates around 5\%, roughly suggesting that two to three times as many firms faced financing obstacles in the crisis compared to the normal state of affairs.

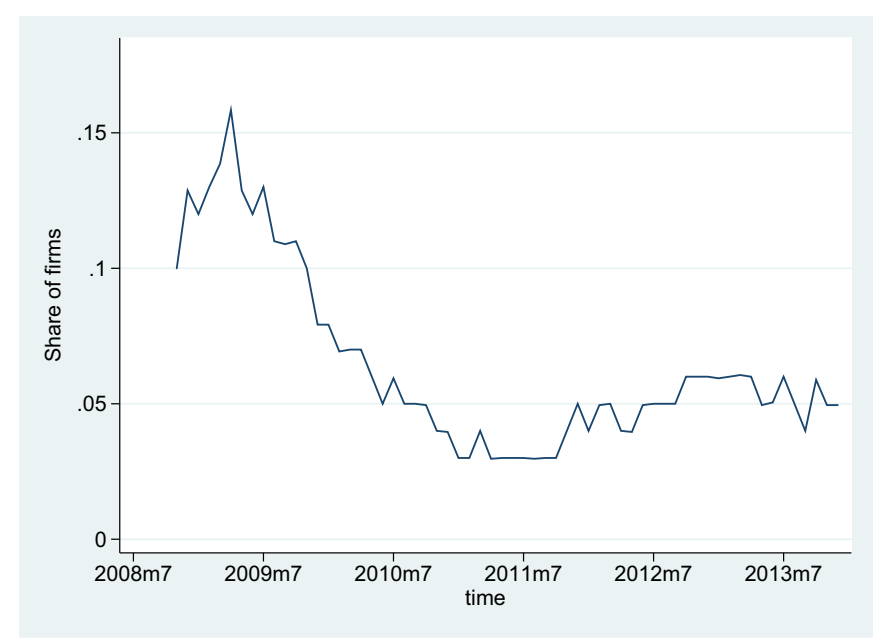

Fig. 1. Reports the fraction of firms responding it is considerably harder than normal to access finance in Sweden. Source: monthly survey "Financing the firm's activities" conducted by National Institute of Economic Research. Note: The survey began in November 2008.

In Fig. 2, we show a breakdown of the reasons why Swedish firms perceived that it was harder to access finance in 2009. More than half of all the respondents (53\%) emphasized that it was harder than normal to access bank loans. It is against this backdrop that the

\footnotetext{
${ }^{4}$ For example, the Swedish government doubled the value of deposit insurance (from 250,000 Swedish Krona (SEK) to 500,000 per person and bank equivalent to about 33,000 and 66,000 US dollars) to mitigate the risk of bank runs, and authorities issued multiple guarantees and programs to support financial institutions. Overall, estimates suggest these efforts to stabilize the financial system cost between 25 and 70 billion SEK ( 3.3 to 9.3 billion US dollars) depending on the time horizon. For additional evidence on Swedish policy efforts in the crisis, see Bergström (2009), Riksbank (2008), and Tillväxtanalys (2013).

${ }^{5}$ From Prop. 2008/09:113 Ökade möjligheter till skatteanstånd. Translated in to English: Expanded possibilities of tax deferral.
} 


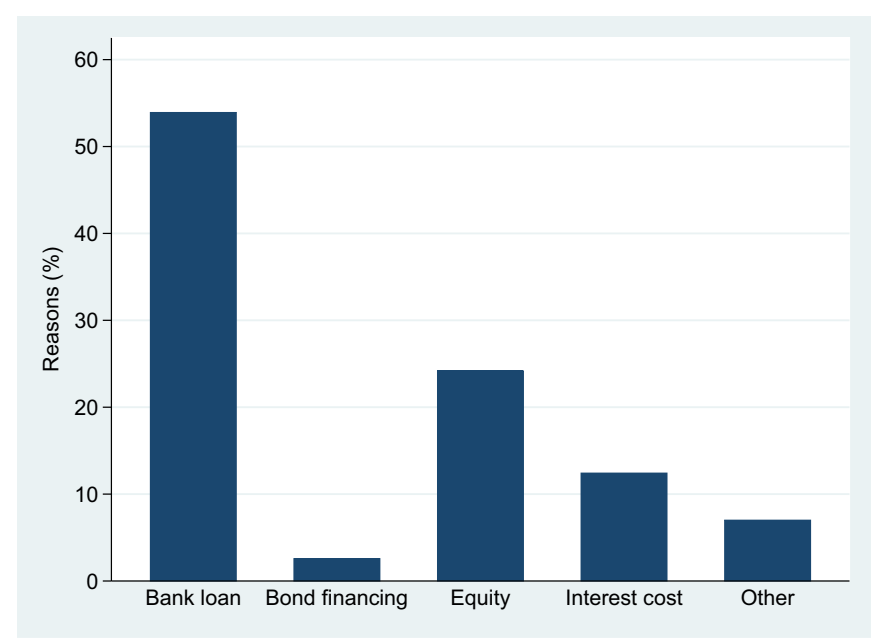

Fig. 2. Reports the distribution of reasons firms gave for why it is harder or much harder than normal to access finance in Sweden. "Bank loan" means firms found it hard to access finance through a bank loan (53.92\% of respondents stated that), "Bond financing" means firms found it hard to access finance through bond financing (2.58\% of respondents stated that), "Equity" means firms found it hard to access finance through issuing new equity (24.17\% of respondents stated that), "Interest cost" means firms found it hard to access finance because of too high interest rates (12.42\% of respondents stated that) and, "Other" means firms found it hard to access finance for some other reason (7.00\% of respondents stated that). Source: monthly survey "Financing the firm's activities" conducted by National Institute of Economic Research.

Swedish parliament passed the tax deferment policy we study.

\subsection{The law of the postponement of labor taxes}

On February 25, 2009, the Swedish parliament passed "the law of the postponement of labor taxes". The initial policy was in effect from March 9, 2009 through the end of 2009, and was administered by the Swedish tax agency (Skatteverket). In January 2010 the government extended the program through the end of 2010, noting that although credit conditions had improved, some firms might still have funding difficulties. ${ }^{6}$

The law allowed firms to postpone paying all labor related taxes and fees, such as employees' income taxes, social security payments, and payroll taxes. The maximum amount a given firm could postpone over the life of the program was capped at twice the monthly amount of total labor fees and taxes. Any delayed payments were treated as a loan from the Swedish government and charged a fixed annual interest rate of approximately 5.3\%. The loans had to be paid in full by January 2011 . The policy was designed to assist firms facing temporary liquidity shortfalls, not to subsidize firms with ample internal cash flows or bail out firms in financial distress, a point stressed by the Swedish government in the original policy proposal.

The Swedish policy has several interesting properties. First, by targeting a firm's labor taxes, firms did not have to be profitable to gain liquidity from the policy. However, because the funding available through the program is a function of labor-related fees, there is substantial heterogeneity across firms in the extent to which they could gain liquidity from the policy. Second, firms participated in the program by checking a box on the monthly labor tax form, making it straightforward for the firm to access the funds and for the tax agency to administer the program. The estimated cost of administration is 16 million SEK (about 2.1 million US dollars), or just 271 SEK per loan (36 US dollars).

Policymakers purposely set the interest rate so as to not crowd out borrowing (if it was available) from traditional financial institutions. It is difficult to quantify the size of the subsidy the program offered to participating firms, as we do not directly observe the marginal (shadow) cost of debt. It is clear that Swedish firms found it more difficult to access bank loans during the time period the lending program was introduced (e.g., Fig. 1 and Fig. 2). In addition, as a point of comparison, senior unsecured bonds issued by nonfinancial firms in the United States had an average spread of 8.3 percentage points in March 2009 (Gilchrist et al. (2012)). Becker and Ivashina (2014) show that small firms switched from bank debt to bonds as bank loan supply contracted in 2008-2009, suggesting that, at least among the firms with some access to debt, the prevailing rate was over $8 \%$. Given that the Swedish banking sector was under similar stress as the US banking sector in 2009 (e.g., the TED spread was around 0.52-0.55 in both the US and Sweden), it is highly likely that private firms in Sweden needing credit faced rates considerably higher than the rate charged by the program.

\footnotetext{
${ }^{6}$ The initial law is SFS 2009:99 Lagen om anstånd med inbetalning av skatt $i$ vissa fall. Translated in to English: The law of tax deferral in certain cases. The extension is Prop. 2009/10:91 Förlängning av tillfälliga anstånd. Translated in to English: Extension of the law of tax deferral in certain cases.
} 
Table 1

Summary statistics.

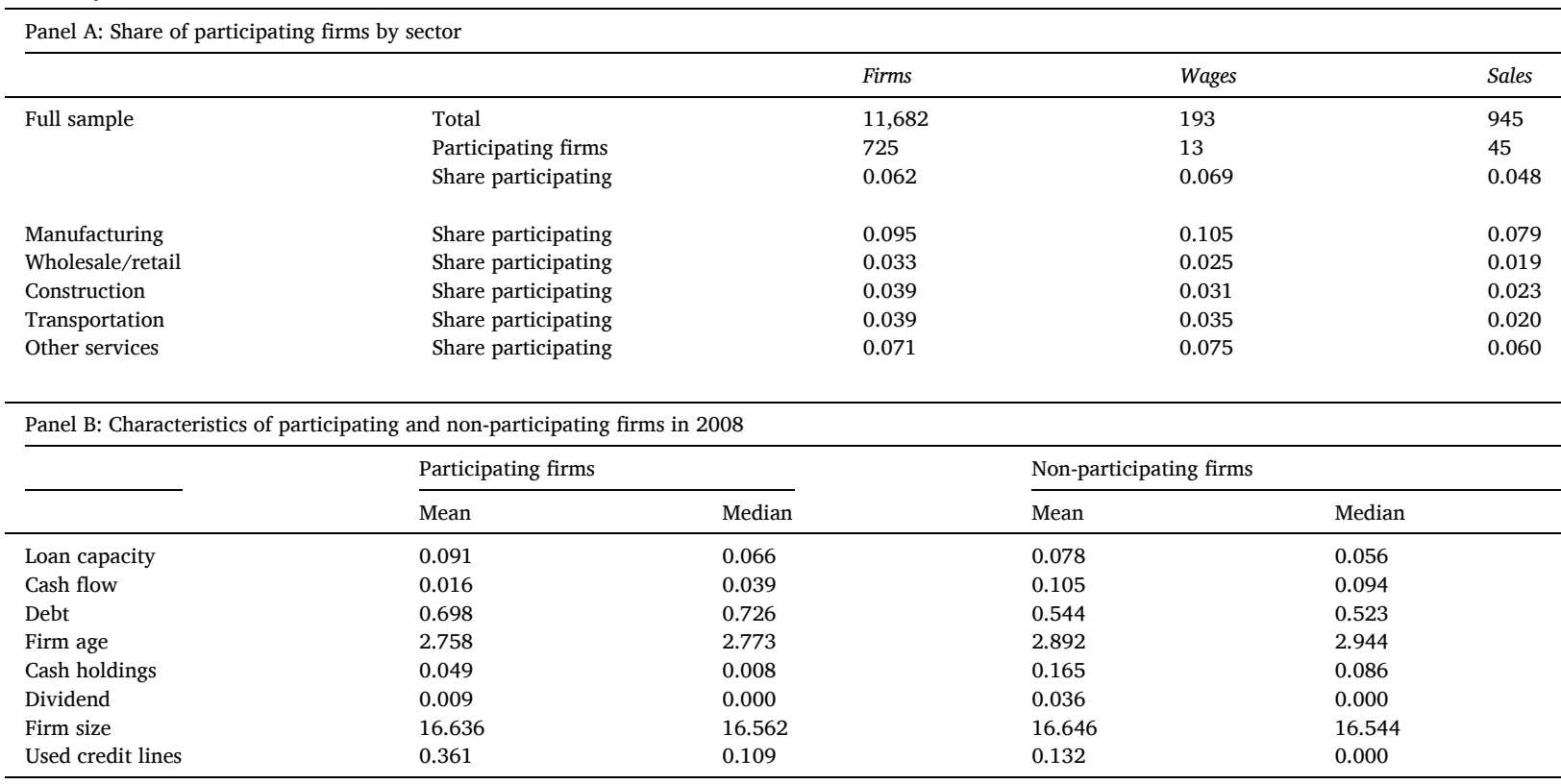

Panel A shows the share of participating firms in the full sample and across different sub-sectors of the economy. Wages and sales are in billion Swedish Krona (SEK) in 2009. Panel B reports mean and median firm characteristics in sub-samples of participating and non-participating firms. Variable definitions are reported in Table A.1.

\section{Who uses temporary lending programs?}

\subsection{Data and sample}

We start with the Firm Register and Individual Database (FRIDA) and financial reporting data from the Swedish Companies Registration Office (Bolagsverket), which is maintained by Statistics Sweden and Bisnode (a private data vendor), respectively. These databases contain balance sheet and income statement information for the entire population of limited liability companies in Sweden. For privacy reasons we cannot see firm names or other public identifiers, but we can track the same firm over time. We focus on limited liability businesses because the vast majority of sole proprietorships in Sweden are one-person, non-growth enterprises (e.g., Åstebro and Tåg, 2017). For example, limited liability corporations account for almost $90 \%$ of total business turnover in Sweden, while sole proprietorships and unlimited partnerships each make up just 1.7\% of total turnover (Tax Statistical Yearbook of Sweden, 2013).

We also use information from the Swedish Tax Agency, who provided details on firm use of the tax deferment policy. All of the data sources have (anonymous) firm-specific identification numbers, which we use to merge information on use of the policy with the firm level data. Table A.1 describes the data source and construction of the main variables we use in the study.

Most of our tests use data for years 2006 to 2009, although for some tests we extend the sample through 2013. We follow the approach in other studies that use administrative data on a broad sample of private firms and require firms to average at least 10 employees per year during the pre-program time period (2006-2008) (e.g., Bach (2014); Caggese et al. (2019)). In the Swedish tax system, it is attractive for individuals to create shell companies for tax planning and income shifting reasons. As a consequence, many of the "firms" in the full administrative database are not active economic enterprises. Nonetheless, all of our findings are similar if we focus on broader sample of firms having at least one employee in the pre-program period. We only include firms with an accounting period equivalent to the calendar year, which is the most common reporting period in Sweden.

We do this to ensure that all firm-level outcomes are evaluated over the same time period. Finally, we exclude firms in financial and regulated industries (codes 64-67 and 35-39 in the EU standard NACE Rev.2 classification).

After cleaning the data, we work with a primary sample of approximately 11,600 firms. The top panel in Table 1 shows that approximately $6 \%$ of these firms used the Swedish lending program. The participating firms accounted for around $7 \%$ of the sample wages and $5 \%$ of sales, figures which are broadly consistent with the official statistics on program usage reported by the Swedish government (e.g., Lagrådsremiss, 2020). Across sectors, firms in manufacturing and services used the program at higher rates than firms in wholesale/retail trade, construction, and transportation. For example, $9.5 \%$ of the manufacturing firms we sample used the 
Table 2

Determinants of loan program participation.

\begin{tabular}{|c|c|c|c|c|}
\hline & (1) & (2) & (3) & (4) \\
\hline Loan capacity & $\begin{array}{l}2.373 \\
(0.894)^{* * *}\end{array}$ & $\begin{array}{l}3.433 \\
(0.917)^{* * *}\end{array}$ & & \\
\hline High loan capacity & & & $\begin{array}{l}0.489 \\
(0.121)^{* * *}\end{array}$ & \\
\hline Q4 loan capacity & & & & $\begin{array}{l}0.898 \\
(0.198)^{* * * *}\end{array}$ \\
\hline Q3 loan capacity & & & & $\begin{array}{l}0.765 \\
(0.166)^{* * * *}\end{array}$ \\
\hline Q2 loan capacity & & & & $\begin{array}{l}0.436 \\
(0.154 * * *\end{array}$ \\
\hline Cash flow & $\begin{array}{l}-1.848 \\
(0.297)^{* * *}\end{array}$ & $\begin{array}{l}-1.837 \\
(0.301)^{* * *}\end{array}$ & $\begin{array}{l}-1.900 \\
(0.303)^{* * *}\end{array}$ & $\begin{array}{l}-1.907 \\
(0.302)^{* * *}\end{array}$ \\
\hline Firm age & $\begin{array}{l}-0.347 \\
(0.071)^{* * *}\end{array}$ & $\begin{array}{l}-0.364 \\
(0.072)^{* * *}\end{array}$ & $\begin{array}{l}-0.360 \\
(0.072)^{* * *}\end{array}$ & $\begin{array}{l}-0.353 \\
(0.071)^{* * *}\end{array}$ \\
\hline Cash holdings & $\begin{array}{l}-5.054 \\
(0.515)^{* * *}\end{array}$ & $\begin{array}{l}-3.975 \\
(0.503)^{* * *}\end{array}$ & $\begin{array}{l}-3.984 \\
(0.505)^{* * *}\end{array}$ & $\begin{array}{l}-4.013 \\
(0.506)^{* * *}\end{array}$ \\
\hline Dividend & $\begin{array}{l}-4.230 \\
(1.504)^{* * *}\end{array}$ & $\begin{array}{l}-3.988 \\
(1.488)^{* * *}\end{array}$ & $\begin{array}{l}-4.101 \\
(1.494) * * *\end{array}$ & $\begin{array}{l}-4.147 \\
(1.494)^{* * *}\end{array}$ \\
\hline Firm size & $\begin{array}{l}0.135 \\
(0.048)^{* * *}\end{array}$ & $\begin{array}{l}0.152 \\
(0.049)^{* * *}\end{array}$ & $\begin{array}{l}0.151 \\
(0.048)^{* * *}\end{array}$ & $\begin{array}{l}0.209 \\
(0.052)^{* * *}\end{array}$ \\
\hline Debt & $\begin{array}{l}2.352 \\
(0.209)^{* * * *}\end{array}$ & $\begin{array}{l}1.906 \\
(0.222)^{* * *}\end{array}$ & $\begin{array}{l}1.990 \\
(0.218)^{* * * *}\end{array}$ & $\begin{array}{l}1.986 \\
(0.221)^{* * * *}\end{array}$ \\
\hline Used credit lines & & $\begin{array}{l}0.971 \\
(0.134)^{* * *}\end{array}$ & $\begin{array}{l}0.957 \\
(0.133)^{* * * *}\end{array}$ & $\begin{array}{l}0.957 \\
(0.134)^{* * *}\end{array}$ \\
\hline Industry fixed effects & Yes & Yes & Yes & Yes \\
\hline Observations & 10,072 & 10,072 & 10,072 & 10,072 \\
\hline Pseudo R-square & 0.167 & 0.178 & 0.179 & 0.181 \\
\hline
\end{tabular}

Logistic regression estimates of Eq. (1) with loan program participation as the dependent variable. Detailed variable definitions are provided in Table A.1. $* * * * *$, and *indicate significance at the $1 \%, 5 \%$, and $10 \%$ levels.

program, and these firms accounted for over $10 \%$ of manufacturing wages and approximately $8 \%$ of sales. Thus, although the overall usage rate for the Swedish program we study here is lower than the take-up rate for similar programs launched during the COVID-19 pandemic, it was used broadly enough to evaluate its effects. ${ }^{7}$

\subsection{Characteristics of participating firms}

The bottom panel in Table 1 summarizes the differences between participating and non-participating firms immediately prior to the crisis. The maximum amount of funding each firm could get from the lending program was twice the monthly amount of labor taxes and fees, which roughly corresponds to $9 \%$ of the firm's total annual wage bill. We thus define each firm's Loan capacity as $9 \%$ of the annual wage bill normalized by book value of total assets. Firms participating in the lending program have higher Loan capacity, consistent with them benefiting relatively more from the funding the program provides. Moreover, the average amount of liquidity a participating firm could get from the program was substantial, corresponding to $9.1 \%$ of total assets.

Participating firms differ from non-participating firms in several other notable ways. Participating firms have less cash in reserve and enter the financial crisis with substantially higher debt-to-asset ratios. Participating firms are also younger, generate less internal cash flow, pay lower dividends, and had already used a larger fraction of their granted credit line when the financial crisis hit. ${ }^{8}$ Overall, participating firms have less ability to tap standard liquidity management tools (i.e., cash reserves and credit lines) to deal with the short-run liquidity shock.

\subsection{Predicting program participation}

The logistic regressions reported in Table 2 provide further evidence on the characteristics associated with use of the government lending program. We estimate the following logistic regression.

$$
\text { Takes } \text { loan }_{i}=\alpha_{1} \text { Loan }_{\text {capacity }}+\alpha_{k} \mathbf{X}_{i}+\eta_{j}+\varepsilon_{i}
$$

where Takes loan is a dummy variable equal to one if the firm delays making labor tax payments in 2009. In addition to the firm's Loan

\footnotetext{
${ }^{7}$ For example, early indications from Sweden point to a much higher take up rate in the most recent economic crisis (e.g., Skatteverket (2020)): $10 \%$ to $15 \%$ of firms had used the program by the end of June 2020 .

${ }^{8}$ An extensive literature studies the role bank credit lines in corporate liquidity management. For example, see Sufi (2009), Jiménez et al. (2009), Demiroglu and James (2011), Acharya et al. (2013), Acharya et al. (2014), Almeida et al. (2014), and Brown et al. (2021).
} 
Table 3

Changes in debt before the loan program.

\begin{tabular}{|c|c|c|c|c|c|c|}
\hline & \multicolumn{6}{|c|}{ Change in } \\
\hline & Total debt & & Bank debt & Non-bank debt & Current assets & Fixed assets \\
\hline & (1) & (2) & (3) & (4) & (5) & (6) \\
\hline \multirow[t]{2}{*}{ High loan capacity } & -0.009 & -0.026 & 0.277 & 0.002 & -0.027 & -0.036 \\
\hline & $(0.02)$ & $(0.02)$ & $(0.219)$ & $(0.02)$ & $(0.018)$ & $(0.03)$ \\
\hline Firm controls & No & Yes & Yes & Yes & Yes & Yes \\
\hline Observations & 744 & 744 & 744 & 744 & 744 & 728 \\
\hline Adj. R-squared & 0.000 & 0.370 & 0.001 & 0.000 & 0.002 & 0.001 \\
\hline
\end{tabular}

OLS estimates of Eq. (2) with Change in total debt as the dependent variable in columns 1-2, Change in bank debt in column 3, Change in non-bank debt in column 4, Change in current assets in column 5, and Change in fixed assets in column 6. All outcomes are averaged over 2006 to 2008 . High loan capacity is a dummy variable equal to one if the firm is above the median in Loan capacity. $Q_{k}$ loan capacity is a dummy variable equal to one if the firm belongs to the $\mathrm{k}^{\text {th }}$ quartile in Loan capacity. Detailed variable definitions are provided in Table A.1. Robust standard errors are in parenthesis; ***, **, and *indicate significance at the $1 \%, 5 \%$, and $10 \%$ levels.

capacity, we include a vector of firm characteristics (X) that may affect the need for liquidity, including Cash flow, Firm age, Cash holdings, Dividend, Firm size, Debt, and Used credit lines. Finally, $\eta_{\mathrm{j}}$ is a set of industry dummy variables, which flexibly controls for industry-specific characteristics that affect the propensity to participate in the lending program.

Column (1) of Table 2 shows that, all else equal, firms with higher Loan capacity are significantly more likely to use the government program. After controlling for Loan capacity, firms are less likely to use the program when they generate more internal cash flow, are older, enter the crisis with higher levels of cash reserves, or make larger dividend payouts. In contrast, leverage ratios and size (total assets) are positively associated with use of the lending program. In general, these findings support the idea that firm use of the lending facility was driven in an important way by financing considerations. The only characteristic that differs from the conventional wisdom in this regard is firm size, which we think is likely due to the broad nature of our sample (covering an unusually large number of very small, private firms). ${ }^{9}$

In column (2) we add the ratio of used-to-granted credit lines to the logistic regression. The coefficient estimate is positive and statistically significant, indicating that the likelihood a firm uses the government program is higher if the firm has already used more of their granted credit line. Controlling for the used-to-granted credit line ratio does not affect any of the other coefficient estimates.

In columns $(3,4)$ we replace the continuous measure of Loan capacity with either: i) the indicator variable High loan capacity, which equals one if the firm's Loan capacity is above the sample median value, or ii) a set of dummy variables indicating the firm's Loan capacity quartile. These estimates show that firms with high Loan capacity are significantly more likely to use the lending program, after controlling for the standard set of firm characteristics that would indicate a need for external finance.

\section{Effects of the Swedish lending program}

\subsection{Empirical specification}

Following Banerjee and Duflo (2014) and Bach (2014), we evaluate the effects of the Swedish program by focusing on changes in firm debt levels. Selection into the lending program is clearly endogenous, so our tests focus on differences in the effects of the program within the sub-set of firms who use of the lending program. These tests exploit the fact that participating firms with higher ex ante Loan capacity were more exposed to (or treated by) the policy, in the sense that they could gain relatively more liquidity than other firms. As we discuss in more detail below, this is an appropriate way to evaluate the program as long as Loan capacity is unrelated to debt growth in the absence of the policy reform.

Using the sub-sample of participating firms, we estimate two types of regressions:

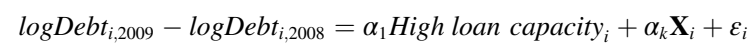

and

$$
\Delta \log \log \text { Debt }_{\mathrm{i}, \mathrm{t}}=\alpha_{1} \text { High loan capacity }_{\mathrm{i}}+\alpha_{2} \text { High loan capacity }_{\mathrm{i}} \text { Post }_{\mathrm{t}}+\eta_{\mathrm{j}}+\eta_{\mathrm{t}}+\varepsilon_{\mathrm{i}, \mathrm{t}}
$$

In Eq. (2), the dependent variable is the log change in debt for firm $i$ from 2008 to 2009. High loan capacity $y_{i}$ is a dummy variable equal to one if the firm's ex ante Loan capacity is above the sample median. In some specifications we replace the High loan capacity $i$ indicator with a series of dummy variables indicating the firm's Loan capacity quartile $\left(Q^{k}\right) . \mathbf{X}_{\mathbf{i}}$ is a vector of the following firm-level control variables (averaged over the pre-loan program period, 2006 to 2008): Cash flow, Firm age, Cash holdings, Dividend, Firm size, Debt, and Used credit lines. This specification collapses the data into one observation per firm, and shows whether debt growth in the year the government program is introduced is higher for firms with High loan capacity compared to other participating firms, after

\footnotetext{
${ }^{9}$ For instance, the average financially constrained firm in Hadlock and Pierce (2010) has a book value of total assets of around 350 million US dollars, which is small relative to other publicly listed US firms, but not at all small in an absolute sense. In sharp contrast, the average book value of total assets among the firms in our sample that used the lending facility is roughly two million US dollars (or SEK 14.8 million).
} 
Table 4

Loan programs and changes in total debt.

\begin{tabular}{|c|c|c|c|c|c|c|}
\hline \multirow[t]{2}{*}{ Dependent variable } & \multicolumn{3}{|c|}{$\log \left(\mathrm{Debt}_{2009}-\mathrm{Debt}_{2008}\right)$} & \multicolumn{3}{|c|}{$\log \left(\right.$ Debt $_{t}-$ Debt $\left._{t-1}\right)$} \\
\hline & (1) & (2) & (3) & (4) & (5) & (6) \\
\hline High loan capacity $x$ Post & & & & $\begin{array}{l}0.118 \\
(0.042)^{* * *}\end{array}$ & $\begin{array}{l}0.118 \\
(0.041)^{* * *}\end{array}$ & $\begin{array}{l}0.112 \\
(0.040)^{* * *}\end{array}$ \\
\hline High loan capacity & $\begin{array}{l}0.117 \\
(0.034) * * *\end{array}$ & $\begin{array}{l}0.107 \\
(0.042)^{* *}\end{array}$ & & $\begin{array}{l}-0.039 \\
(0.024)\end{array}$ & $\begin{array}{l}-0.034 \\
(0.023)\end{array}$ & \\
\hline Q4 loan capacity & & & $\begin{array}{l}0.211 \\
(0.064) * * *\end{array}$ & & & \\
\hline Q3 loan capacity & & & $\begin{array}{l}0.059 \\
(0.054)\end{array}$ & & & \\
\hline Q2 loan capacity & & & $\begin{array}{l}0.003 \\
(0.047)\end{array}$ & & & \\
\hline Firm controls & No & Yes & Yes & No & Yes & No \\
\hline Fixed effects & & & & Ind; Yr & Ind; Yr & Firm; Yr \\
\hline Observations & 721 & 714 & 714 & 2,177 & 2,170 & 2,177 \\
\hline Adj. R-squared & 0.015 & 0.040 & 0.051 & 0.049 & 0.059 & 0.024 \\
\hline
\end{tabular}

OLS estimates of Eq. (2) in columns 1-3, and Eq. (3) in columns 4-6, using only the sub-sample of participating firms. High loan capacity is a dummy variable equal to one if the firm is above the median in Loan capacity. $Q_{k}$ loan capacity is a dummy variable equal to one if the firm belongs to the $\mathrm{k}^{\text {th }}$ quartile in Loan capacity. Detailed variable definitions are provided in Table A.1. Robust standard errors are in parenthesis; ***, **, and *indicate significance at the $1 \%, 5 \%$, and $10 \%$ levels.

conditioning on observable firm characteristics.

Eq. (3) is a standard difference-in-differences regression (e.g., Roberts and Whited (2013); Banerjee and Duflo (2014)). This specification uses a panel of firm-year observations from 2006 to 2009. The coefficient on High loan capacity $x$ Post $t_{t}$ indicates whether the difference in the change in debt between firms with high- and low-Loan capacity is different in the year the program is introduced (2009) compared to other (pre-crisis) years. The year fixed effects $\left(\eta_{\mathrm{t}}\right)$ absorb the uninteracted Post $_{t}$ indicator.

\subsection{Identifying assumption}

Although our approach bypasses concern about endogenous selection into the lending program, our inferences might still be biased if participating firms with high- and low-Loan capacity would have behaved differently in 2009 irrespective of the introduction of the government lending program. Specifically, we are assuming that there would have been no change in the difference in debt usage between firms with high (treated) and low (untreated) Loan capacity in the absence of the lending program.

One way to formally evaluate this concern is to explore whether Loan capacity is correlated with leverage adjustments in the preprogram time period. In Table 3 we report estimates of Eq. (2) with Change in Debt $t_{i}$ (and other balance sheet variables) averaged over 2006 to 2008. High loan capacity is unrelated to changes in total debt, bank debt, and non-bank debt. High loan capacity is also unrelated to changes in assets. These results show that among firms using the temporary lending program, the sub-set of firms with High loan capacity were not already increasing debt levels or expanding assets faster than the participating firms with low loan capacity prior to the introduction of the government program.

\subsection{Baseline results}

We report estimates of Eq. (2) in Table 4. In the first three columns the dependent variable is the log change in total debt between 2008 and $2009 .{ }^{10}$ In column 1 we estimate Eq. (2) without the firm control variables. The coefficient estimate on the High loan capacity indicator is positive and statistically significant, indicating that the change in debt around the implementation of the government lending program is around $12 \%$ larger for participating firms with above median Loan capacity compared to the other participating firms. In column 2 we include the firm control variables and find similar results. Finally, in column 3 we replace the High loan capacity indicator with a set of dummy variables indicating the firm's Loan capacity quartile. The results show that the coefficients are increasing across the Q2-Q4 quartile indicator variables, consistent with a relatively stronger effect in firms with more exposure to the policy. Indeed, the strongest effect (by far) is in firms in the top quartile of Loan capacity: the estimates show that the change in debt is over $20 \%$ larger for firms in the fourth quartile of Loan capacity compared to firms in the first quartile.

In the next three columns we report estimates of Eq. (3). In all specifications, the coefficient on the High loan capacity $x$ Post lo $_{t}$ interaction is positive and statistically significant. The estimates show that the difference in debt growth between firms with above and below median Loan capacity is around 11\% higher in the year the program is introduced (2009) compared to other years. The magnitude of this difference-in-differences estimate is very stable regardless which fixed effects and control variables we include.

10 Following Bach (2014), our specifications use the log change in the level of debt, controlling for log assets in some of the specifications. All of our inferences are similar if we scale the debt variables by total assets before computing the first difference. 
Table 5

Loan programs and other outcomes.

\begin{tabular}{|c|c|c|c|c|c|c|c|c|}
\hline & \multicolumn{8}{|c|}{ Change in } \\
\hline & $\begin{array}{l}\text { Bank debt } \\
\text { (1) }\end{array}$ & (2) & $\begin{array}{l}\text { Non-bank debt } \\
\text { (3) }\end{array}$ & (4) & $\begin{array}{l}\text { Current assets } \\
\text { (5) }\end{array}$ & (6) & $\begin{array}{l}\text { Fixed assets } \\
\text { (7) }\end{array}$ & (8) \\
\hline High loan capacity & $\begin{array}{l}-0.127 \\
(0.463)\end{array}$ & & $\begin{array}{l}0.126 \\
(0.045)^{* * *}\end{array}$ & & $\begin{array}{l}0.081 \\
(0.047)^{*}\end{array}$ & & $\begin{array}{l}-0.031 \\
(0.054)\end{array}$ & \\
\hline Q4 loan capacity & & $\begin{array}{l}-0.036 \\
(0.713)\end{array}$ & & $\begin{array}{l}0.215 \\
(0.070)^{* * *}\end{array}$ & & $\begin{array}{l}0.211 \\
(0.064)^{* * *}\end{array}$ & & $\begin{array}{l}-0.047 \\
(0.084)\end{array}$ \\
\hline Q3 loan capacity & & $\begin{array}{l}0.268 \\
(0.603)\end{array}$ & & $\begin{array}{l}0.100 \\
(0.059) *\end{array}$ & & $\begin{array}{l}0.059 \\
(0.054)\end{array}$ & & $\begin{array}{l}-0.046 \\
(0.071)\end{array}$ \\
\hline Q2 loan capacity & & $\begin{array}{l}0.425 \\
(0.530)\end{array}$ & & $\begin{array}{l}0.017 \\
(0.052)\end{array}$ & & $\begin{array}{l}0.003 \\
(0.047)\end{array}$ & & $\begin{array}{l}-0.019 \\
(0.062)\end{array}$ \\
\hline Firm controls & Yes & Yes & Yes & Yes & Yes & Yes & Yes & Yes \\
\hline Observations & 721 & 714 & 721 & 714 & 713 & 713 & 685 & 685 \\
\hline Adj. R-squared & 0.000 & 0.000 & 0.016 & 0.030 & 0.009 & 0.012 & 0.000 & 0.000 \\
\hline
\end{tabular}

OLS estimates of Eq. (2) with Change in bank debt as the dependent variable in columns 1-2, Change in non-bank debt in columns 3-4, Change in current assets in columns 5-6, and Change in fixed assets in columns 7-8. High loan capacity is a dummy variable equal to one if the firm is above the median in Loan capacity. $Q_{k}$ loan capacity is a dummy variable equal to one if the firm belongs to the $\mathrm{k}^{\text {th }}$ quartile in Loan capacity. Detailed variable definitions are provided in Table A.1. Robust standard errors are in parenthesis; ***, **, and *indicate significance at the $1 \%, 5 \%$, and $10 \%$ levels.

\subsection{Other outcomes}

In Table 5 we explore other outcomes. In the first four columns we look separately at bank and non-bank debt. This test provides a check on our inferences because if the debt growth is due entirely to the introduction of the lending program, only non-bank debt should change. It is also a useful way to check whether firms with High loan capacity would have (differentially) increased debt even in the absence of the lending program - if so, we expect to see increases in debt from sources not associated with the program. The results in columns 1 to 4 show that the overall change in debt for firms with High loan capacity is due only to an increase in non-bank debt.

In the next four columns we explore how access to the lending program affected the asset side of the balance sheet. The estimates in columns 5 and 6 show that firms with higher Loan capacity have relatively faster growth in current assets. For example, the change in current assets for firms in the top quartile of Loan capacity is around 21\% larger than the corresponding change for firms in the lowest quartile of Loan capacity. For changes in fixed assets, on the other hand, there is no significant difference between firms with high and low Loan capacity.

Overall, the results in Table 4 and Table 5 show that firms used the program to increase overall levels of debt, rather than to reduce other liabilities. The effects of the program are relatively stronger in the firms who could gain more liquidity from the program, and only show up in the type of (non-bank) debt that was directly affected by the government loan. Moreover, this additional financing shows up on the asset side of the balance sheet, primarily in terms of relatively higher levels of liquid assets. Given that participating firms are, on average, drawing down current assets in 2009, access to the lending program appears to allow firms to avoid making deeper draws on their internal liquidity at the height of the crisis.

\subsection{Young versus mature firms}

Evidence of faster debt growth in the sub-set of High loan capacity firms is consistent with the idea that the Swedish lending program relaxed binding liquidity constraints in some sub-sets of firms (e.g., Banerjee and Duflo (2014)). If this is indeed the case, we would expect the program to have even stronger (relative) effects in the sub-set of firms that: i) are more financially constrained entering the crisis, and ii) have a higher loan capacity. To identify the firms most likely to be constrained entering the crisis, we split the sample based on firm age, which is a widely used to proxy for financing constraints (e.g., Almeida et al. (2004); Brown et al. (2009)). We then re-estimate the regressions in Table 4 and Table 5 for the young and mature sub-samples. As expected, the effects are generally stronger for young firms with high loan capacity. For example, whereas debt growth in the post program time period is around $11 \%$ higher for firms with high loan capacity compared to firms with low loan capacity, the differential in debt growth is over $15 \%$ higher if we focus only on the young-firm sub-sample.

\subsection{Distress and survival and post-crisis outcomes}

Our final set of tests focus on firm outcomes in the years following the introduction of the government lending facility. ${ }^{11}$ Specifically, we focus on firm survival and financial distress in the post-reform time period. These are arguably the most salient outcomes to evaluate given that one of the primary objectives of a crisis lending program is to help otherwise healthy firms weather the transitory shock. Thus, an important consideration for evaluating lending programs is the extent of financial distress for participating firms after

\footnotetext{
11 One challenge with evaluating long-run outcomes is the sovereign debt crisis, which affected Europe (including Sweden) in the 2011-2012 time period (e.g., Lane (2012)).
} 
Table 6

Loan programs and bankruptcy risk.

\begin{tabular}{|c|c|c|c|c|c|c|}
\hline & \multicolumn{2}{|c|}{ Bankruptcy } & & \multicolumn{3}{|c|}{ Distress } \\
\hline & \multirow{2}{*}{$\frac{2009-10}{(1)}$} & \multirow{2}{*}{$\frac{2009-13}{(2)}$} & \multicolumn{2}{|c|}{$2009-10$} & \multicolumn{2}{|c|}{$2009-13$} \\
\hline & & & (3) & (4) & (5) & (6) \\
\hline High loan capacity & $\begin{array}{l}0.281 \\
(0.512)\end{array}$ & $\begin{array}{l}0.044 \\
(0.297)\end{array}$ & $\begin{array}{l}-0.968 \\
(0.220)^{* * *}\end{array}$ & & $\begin{array}{l}-0.764 \\
(0.210)^{* * *}\end{array}$ & \\
\hline Q4 loan capacity & & & & $\begin{array}{l}-1.356 \\
(0.348)^{* * *}\end{array}$ & & $\begin{array}{l}-1.240 \\
(0.333)^{* * *}\end{array}$ \\
\hline Q3 loan capacity & & & & $\begin{array}{l}-0.935 \\
(0.283)^{* * *}\end{array}$ & & $\begin{array}{l}-0.794 \\
(0.273)^{* * *}\end{array}$ \\
\hline Q2 loan capacity & & & & $\begin{array}{l}-0.127 \\
(0.233)\end{array}$ & & $\begin{array}{l}-0.212 \\
(0.233)\end{array}$ \\
\hline Firm controls & Yes & Yes & Yes & Yes & Yes & Yes \\
\hline Observations & 716 & 716 & 716 & 716 & 716 & 716 \\
\hline Pseudo R-square & 0.047 & 0.047 & 0.094 & 0.097 & 0.103 & 0.107 \\
\hline
\end{tabular}

Logit estimates from estimating Eq. (2) with Bankruptcy in 2009-2010 as the dependent variable in column 1, Bankruptcy in 2009-2013 as the dependent variable in column 2, Distress in 2009-2010 as the dependent variable in columns 3-4, and Distress in 2009-2013 as the dependent variable in columns 5-6. High loan capacity is a dummy variable equal to one if the firm is above the median in Loan capacity. $Q_{k}$ loan capacity is a dummy variable equal to one if the firm belongs to the $\mathrm{k}^{\text {th }}$ quartile in Loan capacity. Detailed variable definitions are provided in Table A. 1 . Robust standard errors are in parenthesis; $* * * * *$, and *indicate significance at the $1 \%, 5 \%$, and $10 \%$ levels.

the program ends.

It is not obvious ex ante how access to the government loan will affect firm financial distress. On one hand, we might expect the government program to improve the odds of survival and reduce the likelihood of financial distress, if the program helped otherwise healthy firms to weather the crisis. On the other hand, as we have shown, participating firms were already highly leveraged going into the crisis, and the program itself added additional debt to the firm's balance sheet. In this way, one concern about government lending programs (that do not offer immediate loan forgiveness) is that participating firms ultimately struggle due to the additional debt burden. In addition, firms may use debt from the government program to pursue riskier activities rather than relax a temporary financing shortfall (e.g., Bach (2014)). If so, it calls into question the wisdom of extending additional credit to these firms in the first place.

The results in Table 6 show that firms with more exposure to the lending program are no more likely to exit than less heavily treated firms, and are less likely to experience severe financial distress. In the first four columns we report estimates of logistic regressions where the dependent variable equals one if the firm files for bankruptcy at any time between 2009 and 2010 (columns 1 and 2) or 2009-2013 (columns 3 and 4). The estimates show that there is no difference in the likelihood of bankruptcy in the post-crisis time period for firms with higher Loan capacity.

As Bach (2014) discusses, bankruptcies are extreme (and unusual) events. We thus proceed in the remainder of Table 6 by replacing the bankruptcy indicator with a measure of financial distress. Specifically, we use the Altman's Z-score formula from Altman and Hotchkiss (2010) to indicate when firms have an episode of "strong" financial distress. ${ }^{12}$ The results show that more heavily treated (higher Loan capacity) firms are significantly less likely to have an episode of strong financial distress in the first two to five years after taking the government loan. These results are not consistent with the idea that temporary lending programs lead to more risk-taking among participating firms.

We also re-estimated the regressions in Table 5 with an expanded post-reform sample period (through 2013). The positive link between the lending program and growth in non-bank debt holds in the expanded sample, but disappears entirely if we drop the year the program is introduced (2009). This evidence is consistent with the idea that the program itself drove the findings we document - $i$. e., firms participating in the government program (with high Loan capacity) increased in non-bank debt as a direct consequence of access to the lending facility in 2009. The results for current assets are similar to the findings for non-bank debt result, although we do see some evidence of growth in current assets in the post-reform period even if we exclude the reform year. Taken together, these findings suggest that firms with high Loan capacity took advantage of the opportunity to borrow in the program year (2009), and then used the proceeds to avoid cuts to current assets in both 2009 and in subsequent years. The results on fixed assets are all close to zero in the extended panel regressions (consistent with the evidence in Table 5).

\section{Discussion and conclusions}

We study the effects of a novel government policy, launched in Sweden in early 2009, which allowed firms to postpone paying all labor-related taxes and fees, treating any unpaid taxes as a loan from the government. We find that the option to temporarily borrow from the government in a crisis appears to be particularly attractive to firms who were already highly leveraged and had already used

\footnotetext{
12 The formula is $\mathrm{Z}=0.717^{*}$ (Net Working Capital/Total Assets $)+0.847 *$ (Retained Earnings/Total Assets) $+3.107 *($ Operating Earnings/Total Assets $)+0.420 *$ (Book Value of Equity/Total Liabilities $)+0.998 *$ (Sales/Total Assets). An episode is "strong" financial distress when the $Z$-score is below 1.23.
} 


\section{Table 7}

Lending programs around the world in response to COVID-19. List of new loan programs launched in OECD countries in 2020. The sources are: OECD, Tax policy measures taken so far (http://www.oecd.org/tax/covid-19-tax-policy-and-other-measures.xlsm) and IBFD Tax Research Platform Covid19 Tax Monitor and Tax Foundation https://taxfoundation.org/coronavirus-country-by-country-responses/. "General” indicates general tax deferral and refers to programs allowing firms to broadly postpone all types of tax payments. "SSC", "PIT", and "VAT" refer to deferral programs where firms can defer payments of social security contributions, personal income taxes, and value added taxes, respectively. "Maturity" is how many months firms can defer payments. "SMES only" indicates that only small and medium sized enterprises are eligible for the program. "All" means there are no additional requirements and all types of firms can defer payments. "Some sectors" indicates that only selected sectors are able to use the program. "Limit" means the amount possible to defer is capped, and "Small only" means that only firms with fewer than 500 workers are eligible.

\begin{tabular}{|c|c|c|c|c|c|}
\hline & General & SSC & PIT & VAT & Maturity \\
\hline Australia & & SMEs only & SMEs only & SMEs only & 4 \\
\hline Austria & & & All & & $5-6$ \\
\hline Belgium & & & All & All & 2 \\
\hline Canada & & & & All & 5 \\
\hline Chile & & & & SMEs only & $3-12^{\mathrm{a}}$ \\
\hline Denmark & & All & All & All & $1-4$ \\
\hline Finland & & & & All & $24^{\mathrm{a}}$ \\
\hline France & & All & & & 3 \\
\hline Germany & All & & & & ${ }_{3} \mathrm{~b}$ \\
\hline Greece & & Some sectors & & Some sectors & 8 \\
\hline Hungary & All & & & & 6 \\
\hline Israel & & All & & All & 1 \\
\hline Italy & & Some sectors & Some sectors & & 6 \\
\hline Japan & All & & & & 12 \\
\hline Netherlands & All & All & All & All & $6^{\mathrm{b}}$ \\
\hline Norway & & All & & All & 2 \\
\hline Poland & & & All & & $3-5$ \\
\hline Portugal & & All & All & All & $3-6$ \\
\hline Slovakia & & All & & & \\
\hline Slovenia & & & All & & $24^{\mathrm{a}}$ \\
\hline Spain & & Limit & & & 6 \\
\hline Sweden (2009) & & All & All & & 24 \\
\hline Sweden & & All & All & All & 12 \\
\hline Switzerland & & All & & & ${ }_{3} \mathrm{~b}$ \\
\hline Turkey & & Some sectors & Some sectors & Some sectors & $6-9$ \\
\hline UK & & & & All & 12 \\
\hline US & & Small only & Small only & & $12-24^{\mathrm{c}}$ \\
\hline
\end{tabular}

${ }^{\text {a }}$ Indicates that firms can pay back in installments.

${ }^{\mathrm{b}}$ Indicates that firms can apply for an extension, and ${ }^{\mathrm{c}}$ indicates that loans can be forgiven in certain cases.

their outstanding lines of bank credit. These firms use the government loan to increase net debt (rather than to substitute for other liabilities) and to prop up current assets. Access to the government loan does not increase bankruptcy risk, and appears to lower the likelihood a firm encounters severe financial distress in the years after the crisis.

Our findings contribute to important literatures on the effects of government lending programs and consequences of financial market disruptions. Despite widespread policy efforts to alleviate credit constraints in smaller firms with loan guarantees and targeted lending programs (e.g., Beck et al. (2010); Bach (2014); Brown and Earle (2017)), there is little or no evidence on policy efforts to mitigate transitory finance shocks. By combining a unique policy directly but temporarily affecting corporate liquidity with administrative data on the full economy of firms, our study provides unique evidence on the potential impact temporary lending programs can have on economic activity.

In this way, our study is also relevant for understanding policy responses to the recent COVID-19 pandemic. As far as we know, the Swedish program was the first of its kind when it was introduced in 2009. In the most recent economic crisis, almost three quarters of the OECD member countries have introduced programs very similar to the program Sweden launched at the height of the financial crisis (see Table 7). It is noteworthy that Sweden itself re-launched the temporary lending program in 2020. The current program is virtually identical to the one we study, although it includes a larger set of taxes that are eligible for deferral, such as value-added taxes.

An obvious topic for future research is to compare and contrast the effects of the COVID-19 programs with the lending facility that we study. In particular, the Swedish reform was introduced in response to a significant shock to the financial sector, whereas the COVID-19 pandemic led to an unprecedented fall in real economic activity (e.g., Baker et al. (2020)). An important question is whether temporary lending facilities are as effective when economic activity declines so sharply. In addition, the COVID-19 programs tended to allow deferral on a wider range of taxes, and thereby likely affected a broader range of firms. As such, there should be more power to evaluate the effects of temporary programs and to identify heterogeneous effects across different types of firms. 


\section{Appendix A}

\section{Table A.1}

Description of the variables.

\begin{tabular}{|c|c|}
\hline Variable & Description \\
\hline Loan capacity & $\begin{array}{l}0.09 \text { multiplied by the total wage bill and then divided by book value of total assets in } 2008 \text {, Winsorized at the } 1 \% \text { level. Source: Statistics } \\
\text { Sweden. }\end{array}$ \\
\hline Cash flow & $\begin{array}{l}\text { Cash flow divided by the beginning of the period book value of total assets averaged during } 2006-2008 \text {, Winsorized at the } 1 \% \text { level. } \\
\text { Source: Statistics Sweden. }\end{array}$ \\
\hline Debt & $\begin{array}{l}\text { Total debt divided by the beginning of the period book value of total assets averaged during 2006-2008, Winsorized at the } 1 \% \text {. Source: } \\
\text { Statistics Sweden. }\end{array}$ \\
\hline Firm age & Natural logarithm of one plus number of years since incorporation averaged during 2006-2008. Source: Statistics Sweden. \\
\hline Cash holdings & $\begin{array}{l}\text { Cash holdings divided by the beginning of the period book value of total assets averaged during 2006-2008, Winsorized at the } 1 \% \text { level. } \\
\text { Source: Statistics Sweden. }\end{array}$ \\
\hline Dividend & $\begin{array}{l}\text { Dividend divided by the beginning of the period book value of total assets averaged during 2006-2008, Winsorized at the } 1 \% \text { level. Source: } \\
\text { Statistics Sweden. }\end{array}$ \\
\hline Firm size & Natural logarithm of book value of total assets averaged during 2006-2008, Winsorized at the 1\% level. Source: Statistics Sweden. \\
\hline Used credit lines & The ratio between used to granted credit lines in 2008, Winsorized at the $1 \%$ level. Source: Statistics Sweden. \\
\hline Change in total debt & Log difference in total debt between 2008 and 2009, Winsorized at the $1 \%$ level. Source: Statistics Sweden. \\
\hline Change in bank debt & Log difference in bank debt between 2008 and 2009, Winsorized at the 1\% level. Source: Statistics Sweden. \\
\hline $\begin{array}{l}\text { Change in non bank } \\
\text { debt }\end{array}$ & Log difference in non bank debt between 2008 and 2009, Winsorized at the 1\% level. Source: Statistics Sweden. \\
\hline Change in total assets & Log difference in book value of total assets between 2008-2009, Winsorized at the $1 \%$ level. Source: Statistics Sweden. \\
\hline Change in fixed assets & Log difference in book value of fixed assets between $2008-2009$, Winsorized at the $1 \%$ level. Source: Statistics Sweden. \\
\hline $\begin{array}{l}\text { Change in current } \\
\quad \text { assets }\end{array}$ & Log difference in book value of current assets between 2008-2009, Winsorized at the 1\% level. Source: Statistics Sweden. \\
\hline Bankruptcy & Indicator variable taking on the value 1 if the firm files for bankruptcy and zero otherwise. Source: Statistics Sweden. \\
\hline Distress & $\begin{array}{l}\text { Indicator variable taking on the value one if the firm is below } 1.23 \text { in terms of Altman Z-score. Source: Other's own calculations and } \\
\text { Statistics Sweden. }\end{array}$ \\
\hline
\end{tabular}

\section{References}

Acharya, V.V., Almeida, H., Campello, M., 2013. Aggregate risk and the choice between cash and lines of credit. J. Financ. 68, $2059-2116$.

Acharya, V., Almeida, H., Ippolito, F., Perez, A., 2014. Credit lines as monitored liquidity insurance: theory and evidence. J. Financ. Econ. 112, 287-319.

Almeida, H., 2021. Liquidity management during the covid-19 pandemic. Asia Pac. J. Financ. Stud. 50, 7-24.

Almeida, H., Campello, M., Weisbach, M.S., 2004. The cash flow sensitivity of cash. J. Financ. 59, $1777-1804$.

Almeida, H., Campello, M., Cunha, I., Weisbach, M.S., 2014. Corporate liquidity management: a conceptual framework and survey. Annu. Rev. Fin. Econ. 6, 135-162.

Altman, E.I., Hotchkiss, E., 2010. Corporate Financial Distress and Bankruptcy: Predict and Avoid Bankruptcy, Analyze and Invest in Distressed Debt, 289. John Wiley \& Sons.

Armstrong, C.S., Blouin, J.L., Larcker, D.F., 2012. The incentives for tax planning. J. Account. Econ. 53, 391-411.

Åstebro, T., Tåg, J., 2017. Gross, net and new job creation by entrepreneurs. J. Bus. Ventur. Insights 8, 64-70.

Bach, L., 2014. Are small businesses worthy of financial aid? Evidence from a French targeted credit program. Rev. Fin. 18, 877-909.

Baker, S.R., Bloom, N., Davis, S.J., Terry, S.J., 2020. Covid-Induced Economic Uncertainty. Tech. rep.. National Bureau of Economic Research.

Banerjee, A.V., Duflo, E., 2014. Do firms want to borrow more? Testing credit constraints using a directed lending program. Rev. Econ. Stud. 81, 572-607.

Beck, T., Klapper, L.F., Mendoza, J.C., 2010. The typology of partial credit guarantee funds around the World. J. Financ. Stab. 6, $10-25$.

Becker, B., Ivashina, V., 2014. Cyclicality of credit supply: firm level evidence. J. Monet. Econ. 62, 76-93.

Berger, A.N., Cerqueiro, G., Penas, M.F., 2015. Market size structure and small business lending: are crisis times different from normal times? Rev. Fin. 124, 1965-1995.

Bergström, C., 2009. Finanskrisen och den svenska krishanteringen under hösten 2008 och vintern 2009, Finanspolitiska r adet Stockholm.

Bliss, B.A., Cheng, Y., Denis, D.J., 2015. Corporate payout, cash retention, and the supply of credit: evidence from the 2008-2009 credit crisis. J. Financ. Econ. 115, $521-540$.

Brown, J.D., Earle, J.S., 2017. Finance and growth at the firm level: evidence from SBA loans. J. Financ. 72, 1039-1080.

Brown, J.R., Petersen, B.C., 2015. Which investments do firms protect? Liquidity management and real adjustments when access to finance falls sharply. J. Financ. Intermed. 24, 441-465.

Brown, J.R., Fazzari, S.M., Petersen, B.C., 2009. Financing innovation and growth: cash flow, external equity and the 1990 s R\&D boom. J. Financ. 64, 151-185.

Brown, J.R., Gustafson, M.T., Ivanov, I.T., 2021. Weathering cash flow shocks. J. Financ. 76, 1731-1772.

Caggese, A., Cunat, V., Metzger, D., 2019. Firing the wrong workers: financing constraints and labor misallocation. J. Financ. Econ. $133,589-607$.

Campello, M., Graham, J.R., Harvey, C.R., 2010. The real effects of financial constraints: evidence from a financial crisis. J. Financ. Econ. $97,470-487$.

Casey, E., O'Toole, 2014. Bank lending constraints, trade credit and alternative financing during the financial crisis: evidence from European SMEs. J. Corp. Finan. 27, 173-193.

Claessens, S., Dell'Ariccia, G., Igan, D., Laeven, L., 2010. Cross-country experiences and policy implications from the global financial crisis. Econ. Policy 62, 267-293. Demiroglu, C., James, C., 2011. The use of bank lines of credit in corporate liquidity management: a review of empirical evidence. J. Bank. Financ. 35, 775-782. Denis, D.J., 2011. Financial flexibility and corporate liquidity. J. Corp. Finan. 17, 667-674.

Duchin, R., Ozbas, O., Sensoy, B.A., 2010. Costly external finance, corporate investment, and the subprime mortgage credit crisis. J. Financ. Econ. 97, 418-435. Edwards, A., Schwab, C., Shevlin, T., 2016. Financial constraints and cash tax savings. Account. Rev. 91, 859-881.

Fernández, A.I., González, F., Suárez, N., 2018. Bank supply shocks and the substitution between bank and nonbank debt. J. Corp. Finan. 48 , $122-147$.

French, K., Baily, M., Campbell, J., Cochrane, J., Diamond, D., Duffie, D., Kashyap, A., Mishkin, F., Rajan, R., Scharfstein, D., et al., 2010. The Squam Lake report: fixing the financial system. J. Appl. Corporate Fin. 22, 8-21. 
Gilchrist, S., Sim, J.W., Zakrajsek, E., 2012. Credit spreads and business cycle fluctuations. Am. Econ. Rev. 102, $1692-1720$.

Hadlock, C.J., Pierce, J.R., 2010. New evidence on measuring financial constraints: moving beyond the KZ index. Rev. Financ. Stud. 23, $1909-1940$.

Jiménez, G., Lopez, J.A., Saurina, J., 2009. Empirical analysis of corporate credit lines. Rev. Financ. Stud. 22, 5069-5098.

Lagrådsremiss, 2020. Atgarder med anledning av coronaviruset. Lagrådet, 16 mars.

Lane, P.R., 2012. The European sovereign debt crisis. J. Econ. Perspect. 26, 49-68.

Lelarge, C., Sraer, D., Thesmar, D., 2010. Entrepreneurship and credit constraints: evidence from a French loan guarantee program. In: International Differences in Entrepreneurship, pp. 243-273.

Ohrn, E., 2019. The effect of tax incentives on US manufacturing: evidence from state accelerated depreciation policies. J. Public Econ. $180,104084$. Riksbank, 2008. Financial Stability Report 2008:2. Swedish Central Bank.

Roberts, M.R., Whited, T.M., 2013. Endogeneity in empirical corporate finance1. In: Handbook of the Economics of Finance, 2. Elsevier, pp. $493-572$.

Schularick, M., Taylor, A.M., 2012. Credit booms gone bust: monetary policy, leverage cycles, and financial crises, 1870-2008. Am. Econ. Rev. 102, 1029-1061.

Shevlin, T., Shivakumar, L., Urcan, O., 2019. Macroeconomic effects of corporate tax policy. J. Account. Econ. 68, 101233.

Skatteverket, 2020. Indikatorer for att folja de ekonomiska konsekvenserna av covid-19.

Sufi, A., 2009. Bank lines of credit in corporate finance: an empirical analysis. Rev. Financ. Stud. 22, 1057-1088.

Tax Statistical Yearbook of Sweden, 2013. Skatteverket.

Taylor, J.B., 2009. The Financial Crisis and the Policy Responses: An Empirical Analysis of What Went Wrong. National Bureau of Economic Research.

Tillväxtanalys, 2013. "Kartläggning av politiska insatser under finanskrisen 2008-2009," Policy Working Paper 2013:01. Tillväxtanalys.

Zwick, E., Mahon, J., 2017. Tax policy and heterogeneous investment behavior. Am. Econ. Rev. 107, $217-248$. 